\title{
Moringa Leaves Flour and Tengger Potato Flour as Composite Flour for GFCF Diets
}

\author{
Titi Mutiara Kiranawati ${ }^{1}$, Budi Wibowotomo ${ }^{2,}$ Nunung Nurjanah ${ }^{3}$ \\ ${ }^{1,2,3}$ Department of Industrial Technology, Faculty of Engineering, Universitas Negeri Malang \\ Corresponding author, Email: titi.mutiara.ft@um.ac.id
}

\begin{abstract}
Composite flour ratio Tengger potato starch and flour made with the aim of Moringa leaves as a substitute for wheat flour containing gluten and casein to be used as raw material products GFCF (Gluten Free Casein Free). The experimental design use completely randomized design consisted of four treatments (ratio of Tengger's potato starch and moringa leaf powder 100\%: 0\%, 96\%: 4\%, 95\%: 5\% and 94\%: 6\%) and three replications; and then analyzed to determine the proximate contents (water, ash, protein, fat, crude fiber, carbohydrates) and physical properties (color, water absorption, temperature gelatinization starch). Data were statistically tested using ANOVA and Duncan's Multiple Range Test (DMRT). Results showed that the ratio of composite flour and potato starch flour Moringa leaves Tengger significantly different with the content of the proximate and physical properties. The best composite flour which is approaching the characteristics of wheat flour is composite flour with a ratio of potato starch Tengger and flour of Moringa leaves 94\%: 6\% moisture content $9.940 \mathrm{~g} / 100 \mathrm{~g}$, ash content of $2.045 \mathrm{~g} / 100 \mathrm{~g}$, protein content of $3.090 \mathrm{~g} /$ $100 \mathrm{~g}$, levels $0.286 \mathrm{~g}$ fat / $100 \mathrm{~g}$, crude fiber content of $0.597 \mathrm{~g} / 100 \mathrm{~g}$, carbohydrate levels $84.638 \mathrm{~g} / 100 \mathrm{~g}$, and the physical properties include brightness level of 82.79, the value of 1.56 greenish, yellowish 59.66 value, water absorption $129.861 \%$, and the starch gelatinization temperature $62,5 \mathrm{oC}$. Composite flour potato starch ratio Tengger and moringa leaf powder can be used in products that do not require high development namely pastry products such as cookies and snacks.
\end{abstract}

Keywords: GFCF, Tengger's potato starch, Moringa leaf powder, flour composites, optimization

\section{INTRODUCTION}

Food that had been circulating in the market as most of the snacks made from wheat flour. Wheat flour is a food that should be avoided by people with autism because they contain gluten and casein (Astuti, 2016). The food was outstanding, the food should be avoided by people with autism. So, we need dietary therapy called GFCF diet (Abata, 2014).

GFCF diet (Gluten Free Casein Free) is a diet that is done by not eating foods that contain gluten and casein (the protein in milk). GFCF diet is usually done by people with autism because foods containing protein (gluten and casein) can not be digested by people with autism. GFCF diet is usually low in protein (Herminiati 2009 and Abata, 2014). Khoirunnisa and Judiono (2018) observed that many children with autism who do not implement the GFCF diet and still eat foods containing gluten and casein such as biscuits, wafers, crackers, ice cream and so on .

Foodstuffs abundant and cheap in East Java is the potato. It produced largest income in East Java and mostly located in Tengger area of Bromo and Junggo area, Kodya Batu (Maulida, 2015 and Hidayat, 2017). The potential cultivated land of Tengger potatoes is by 600 hectares with a potential average yield of 38-50 tonnes / ha (Hand, 2016). In addition the use of potatoes Tengger was not maximized, so it needs to be maximized utilization to process them into food products. Yulianto research results (2019) states that protein content $(2.249 \%)$ of Tengger potato is higher than Junggo potatoes $(2.213 \%)$. The proximate content of Tengger potato are of protein $22.49 \%$, $0149 \%$ fat, carbohydrates $20.31 \%$, water 76 $105 \%$, and ash $1,142 \%$. It has high in carbohydrates, but low in protein, whereas people with autism require high protein (Winarno, 2013). So that needs to be made of flour mixture called composite flour.

According Widowati (2009), the composite flour is flour made from two or more foodstuffs. Composite flour made with the aim to replace wheat flour. Composite flour could increase its use as a food ingredient variants of gluten and casein-free (GFCF) for people with autism.

Good composite flour approaching the physical quality requirements of flour, among other forms of powders $/$ granules, normal / no smell other materials, the fineness of the flour passes 70 mesh sieve as much as $95 \%$, free from contamination (microbial and metal), and contains chemical elements include the maximum moisture content of $14.5 \%$, a maximum ash content of $0.70 \%$, protein content of at least $7.0 \%, 1.07 \%$ fat and fiber content of $0.25 \%$, and $73.52 \%$ carbohydrate (SNI 2009; Princess, 2014). Potato flour contains less protein composite that needs to be added to foods high in protein.

One of the high-protein food, cheap, readily available, and widely grown in Indonesia is moringa (Nurcahyati, 2014). According to Winarno (2018), Moringa leaf is a functional food that is considered a superfood mega (super food) is a food that has a high concentration of the nutrient and phytochemical content which is very beneficial for human health. Dried Moringa leaves as much as 100 grams contains nutrients are protein $29.4 \mathrm{~g}$, fat $5.2 \mathrm{~g}$, carbohydrates 41.2 grams and 12.5 grams of fiber. The content contained in 100 grams of Moringa leaf powder is 205 cal calories, 27.1 grams protein, 2.3 grams fat, $38.2 \mathrm{~g}$ carbohydrates and 19.2 gram fiber (Gopalakrishnan et al, 2016). According to research Kiranawati et al (2012), the 
best Moringa leaf powder was produced by blanching method for 5 minutes, and it contain $30.68 \%$ protein. Manufacture of composite flour consisted of ratio Tengger potato starch and Moringa leaf powder was aimed to obtain a composite flour nongluten and nonkasein as an alternative substitute for wheat flour to be used as raw material GFCF products. The study will analyze the content of the proximate (water, ash, protein, fat, crude fiber, and carbohydrates) .and physical properties (color, water absorption, and the starch gelatinization temperature) on the composite ratio of potato starch flour Tengger and moringa leaf powder.

\section{METHODS}

Research conducted was an experimental study. The study design used completely randomized design (CRD) contain a factor which is ratio of Tengger potato starch and flour of Moringa leaves by four levels of 100\%: $0 \%, 96 \%: 4 \%$, 95\%: $5 \%$ and 94\%: $6 \%$. The replications are 3 times so that a total of 12 experimental units.

The main ingredient in the manufacture of composite flour is potato flour Tengger and moringa leaf powder. Tengger materials for potato starch (Solanum tuberosum) is Tengger fresh potatoes, oval, white or yellow skin, not physically and chemically, taken from the village of Krajan, Tengger. Moringa leaf powder manufacturing material is the leaves of Moringa (Moringa oliefera) fresh harvested in the third and fourth stalk that blooms from the end of the petiole is still young and have never bear fruit earlier, were taken from the village Landungsari, Malang. The materials used for the analysis is a sample of composite flour consisted of ratio of Tengger potato starch and flour Moringa leaves; silica gel, active lime, sulfuric acid, aluminum oxide, potassium sulfate, barium oxide, mercury oxide $(\mathrm{HgO})$, sodium hydroxide, hydrochloric acid, a solution red indicator.

The tools used in the manufacturing process of composite flour is a decimal scale, spoon, bowl, food processor, jar. The tools used in the manufacture of potato starch Tengger is peeler, knife, cutting board, basin, decimal scales, measuring cups, stove, steaming, baking, cabinet dryer, blender, scoop. The tools used in the manufacturing process of Moringa leaf powder is a basin, decimal scales, cookers, pans, strainer, pan, cabinet dryer, blender, scoop. The tools used for the analysis of the content of the proximate are oven, desiccator, saucer, analytical balance, furnace, clamp plate, heating Kjeldhal, aspirator, distillation apparatus, burettes, magnetic stirrer, Erlenmeyer, mortar, pestle, tube extraction Soxhlet, thimble, heating mantle, rotary evaporator, extraction tubes, turning cooler, filter paper, litmus paper, Gooch crucible.

The analysis used in this research is the analysis of the content of the proximate include moisture content using the oven (AOAC, 2016), ash content using the Furnace (AOAC, 2011), protein content using the Semi-Micro Kjeldahl (AOAC, 2016), fat content using methods Soxhlet (AOAC, 2011), the crude fiber content using the Acid Alkaline Digestion (AOAC, 2016), and the carbohydrate content using methods By Difference (AOAC, 2011), as well as physical properties include color using the color reader (AOAC, 2016), power water absorption method Gravimetry (Minerva, 2013), and the gelatinization temperature of starch using the temperature of Gel Forming Measurement (AOAC, 2011) on the composite flour ratio potato starch Tengger and flour of Moringa leaves 100\%: 0\%, 96\%: 4\%; 95\%: 5\% and 94\%: $6 \%$.

Data obtained from the analysis of the content of the proximate and physical properties were tested using One Way ANOVA with a significance level of $5 \%$. if there is significant differences (significant) then proceed test Duncan's Multiple Range Test (DMRT) to determine the level of difference in each treatment.

\section{RESULTS AND DISCUSSION}

\section{Proximate Analysis}

The mean results of the proximate content analysis of composite flour potato starch ratio Tengger and moringa leaf powder 100\%: $0 \%, 96 \%$ : $4 \%, 95 \%: 5 \%$ and $94 \%: 6 \%$ can be seen in Table 1 .

Table 1. Proximate Analysis Results Mean Content Ratio Composite Flour Potato Flour And Wheat Leaf Tengger Kelor

\begin{tabular}{|c|c|c|c|c|c|c|}
\hline \multirow{2}{*}{$\begin{array}{c}\text { Formula } \\
\text { (TKT: TDK) }\end{array}$} & \multirow[b]{2}{*}{$\begin{array}{l}\text { Wate } \\
\mathbf{r}(\mathrm{g} / \\
100 \mathrm{~g})\end{array}$} & \multirow[b]{2}{*}{$\begin{array}{l}\text { Ash (g } \\
/ 100 \mathrm{~g})\end{array}$} & \multicolumn{2}{|c|}{ contents proximate } & \multirow[b]{2}{*}{$\begin{array}{l}\text { Crude Fiber } \\
\quad(\mathrm{g} / 100 \mathrm{~g})\end{array}$} & \multirow[b]{2}{*}{$\begin{array}{l}\text { Carbohydrat } \\
\text { es (g/100 } \\
\text { g) }\end{array}$} \\
\hline & & & $\begin{array}{l}\text { Protein } \\
(\mathrm{g} / 100 \\
\text { g) }\end{array}$ & $\begin{array}{l}\text { Fat (g/ } \\
100 \mathrm{~g})\end{array}$ & & \\
\hline $100 \%: 0 \%$ & $9,490 \mathrm{a}$ & $1.842 \mathrm{a}$ & $2.296 \mathrm{a}$ & $0,113 \mathrm{a}$ & $0.399 \mathrm{a}$ & $86.259 \mathrm{a}$ \\
\hline $96 \%: 4 \%$ & $9,649 \mathrm{a}$ & $1.946 \mathrm{~b}$ & $2.766 \mathrm{~b}$ & $0.213 \mathrm{~b}$ & $0.498 \mathrm{~b}$ & $85.425 \mathrm{~b}$ \\
\hline $95 \%: 5 \%$ & $9,877 b$ & $2,012 \mathrm{c}$ & $2,940 \mathrm{c}$ & $0,253 \mathrm{c}$ & $0,548 \mathrm{c}$ & $84.918 \mathrm{c}$ \\
\hline $94 \%: 6 \%$ & $9,940 \mathrm{~b}$ & $2.045 \mathrm{~d}$ & $3,090 \mathrm{~d}$ & $0.286 \mathrm{~d}$ & $0,597 \mathrm{~d}$ & $84.638 \mathrm{~d}$ \\
\hline
\end{tabular}

Description: TKT = Flour Chips Tengger, TDK = Wheat Leaf Moringa, notations the same letters states are not significantly different treatments 
Statistical results showed that there were significant differences in water content, ash, protein, fat, crude fiber, and carbohydrate of composite flour consisted Tengger potato starch and moringa leaf powder ratio. The more the ratio of Moringa leaf powder, so increasing the water content. Composite flour with potato starch ratio Tenger and moringa leaf powder 94\%: 6\% had the highest water content of 9.940 grams / 100 grams.

Differences between the mean water content of the composite powder is probably due Moringa leaf powder has a moisture content ( 9.57 grams / 100 grams) was higher than the Tengger potato starch (9.49 grams / 100 grams) (Agustin, 2017). So, if the ratio of the Tengger potato starch flour is reduced and the ratio of Moringa leaf increases will produce composite flour which has a water content increases. In addition, the water content in the composite flour increased allegedly high content of protein in Moringa leaf powder, because proteins can bind water. So that the increasing ratio of Moringa leaf powder, the water content tends to increase composite flour (Trisnawati \& Nisa, 2015). The water content of the composite flour potato starch ratio Tengger and moringa leaf powder ranging from 9.49 to 9 ,

In the ash content, results showed that the more the ratio of Moringa leaf powder, then increasing ash content. Composite flour with potato starch ratio of Tengger and moringa leaf powder $94 \%$ : $6 \%$ had the highest ash content of 2.045 grams / 100 grams. Based on the results of the analysis of the ash content of flour Tengger potato is 1.842 grams / 100 grams. While the ash content of Moringa leaf powder as much as 7.85 grams / 100 grams (Agustin, 2017).

The ash content indicates mineral content in a material. According to Winarno (2004) on an ash content of food will increase as the number of the mineral content in the food material. The ash content of potato starch flour composite ratio Tengger and moringa leaf powder that ranged from 1.842 to 2.045 grams / 100 grams still exceeds the criteria of ISO ash content of the flour is a maximum of $0.7 \%$ (BSN, 2009).

The results of protein content showed that the more the ratio of Moringa leaf powder, then increasing the protein content. Composite flour with potato starch ratio of Tengger and moringa leaf powder 94\%: 6\% had the highest protein content of 3.090 grams / 100 grams. Differences between the mean composite flour protein content is apparently due Moringa leaf powder that has a high protein content (30.68 grams / 100 grams) (Kiranawati et al, 2012).

The protein content of potato starch flour composite ratio Tengger and moringa leaf powder does not meet ISO standards for levels flour highest preotein the composite flour is 3.090 grams / 100 grams, while SNI to the wheat flour protein content of at least 7.0 grams / 100 grams (BSN, 2009). The results of the study of composite flour sweet potatoes, potatoes, and soy protein content of the resulting states ranged from 3.27 to 5.64 grams / 100 grams (Ginter et al, 2015). Low levels of protein in the composite flour is because the ratio of Moringa leaf powder is used very little so it does not rise high levels of protein in the composite flour potato starch ratio Tengger and moringa leaf powder. Composite flour with potato starch ratio of Tengger and flour Moringa leaves contain low protein content but are free of gluten and casein,

The results of the fat content data showed that the more ratio of Moringa leaf powder, then increasing the fat content. Composite flour with potato starch ratio of Tengger and moringa leaf powder 94\%: $6 \%$ had the highest fat content of 0.286 grams / 100 grams. Differences in the average fat content of composite flour is apparently due to the fat content of Moringa leaf powder is higher than that of potato starch Tengger 2.25 grams / 100 grams (Agustin, 2017). A fat content of foodstuffs supposed to influence the tenderness and flavor enhancer in the resulting product, so the more fat composite flour pastry tends to affect the resulting product (Paradibta, 2011). Research of Putri (2014) explains that the fat content of wheat flour of 1.07 grams / 100 grams. When compared with the research that produced the fat content is low.

The results on the crude fiber content showed that the more the ratio of Moringa leaf powder, then increasing fiber content. Composite flour with potato starch ratio of Tengger and moringa leaf powder 94\%: 6\% has the highest crude fiber content is 0.597 grams / 100 grams. Differences in average crude fiber content of composite flour is presumably because crude fiber content of Moringa leaf powder (2.52 grams / 100 grams) than the potato starch Tengger (0,339 grams / 100 grams) (Agustin, 2017).

The resulting crude fiber content of composite flour potato starch ratio Tengger and moringa leaf powder is similar to wheat flour for the highest fiber content of the composite powder that is 0,597 grams / 100 grams, while the crude fiber content of the flour of 0.25 grams / 100 grams (Putri, 2014). Research Amalia (2014) states composite flour sweet potato, potato, soybean and xanthan gum produces crude fiber content ranges from 0.99 to 1.96 grams / 100 grams.

The results on the carbohydrate content showed that the more the ratio of Moringa leaf powder, then decreasing levels of carbohydrates. Reduced levels of carbohydrates in the potato starch composite flour ratio Tengger and moringa leaf powder caused by an increase in the content of other proximate (by different). Composite flour with potato starch ratio of Tengger and moringa leaf powder 100\%: $0 \%$ has the highest carbohydrate content is 86.259 grams / 100 grams. According Krisnadi (2015) Moringa leaf powder carbohydrate levels as much as 48.4 grams / 100 grams. Composite flour carbohydrate content of potato starch ratio Tengger and moringa leaf powder (84.638 grams / 100 grams) than white flour carbohydrate content of 77.3 grams / 100 grams) (Martawijaya et al, 2004), Likewise with the results Putri (2014), which stated carbohydrate content of 73.52 grams / 100 grams.

\section{Physical Properties}

The mean results of the analysis of physical properties of composite flour potato starch ratio Tengger and moringa leaf powder 100\%: $0 \%, 96 \%$ : $4 \%, 95 \%$ : $5 \%$ and $94 \%$ : $6 \%$ can be seen in Table 2 . 
Table 2. Average Analysis Physical Properties of Composite Flour Potato Flour ratio Tengger And Flour Moringa Leaves

\begin{tabular}{|c|c|c|c|c|c|}
\hline \multirow{3}{*}{$\begin{array}{c}\text { Formula } \\
\text { (TKT: TDK) }\end{array}$} & \multirow[b]{3}{*}{$\mathbf{L}$} & \multicolumn{4}{|c|}{ Physical Properties } \\
\hline & & \multirow{2}{*}{$\frac{\text { Color }}{\text { a- }}$} & \multicolumn{2}{|c|}{ Water } & \multirow{2}{*}{$\begin{array}{c}\text { Starch Gelatinization } \\
\text { temperature } \\
(\text { oC) }\end{array}$} \\
\hline & & & $\mathbf{b}+$ & $\begin{array}{l}\text { Absorptio } \\
\text { n }(\%)\end{array}$ & \\
\hline $100 \%: 0 \%$ & $88.59 \mathrm{a}$ & $0.36 \mathrm{a}$ & $65.51 \mathrm{a}$ & $124.395 \mathrm{a}$ & $60.8 \mathrm{a}$ \\
\hline $96 \%: 4 \%$ & $86.46 \mathrm{~b}$ & $0.98 \mathrm{~b}$ & $62.77 \mathrm{~b}$ & $126.953 \mathrm{~b}$ & $61.4 \mathrm{~b}$ \\
\hline $95 \%: 5 \%$ & $85.21 \mathrm{c}$ & $1.26 \mathrm{c}$ & $61.67 \mathrm{c}$ & $128.281 \mathrm{c}$ & $61.9 \mathrm{c}$ \\
\hline $94 \%: 6 \%$ & $82.79 \mathrm{~d}$ & $1.56 \mathrm{~d}$ & $59.66 \mathrm{~d}$ & $129.861 \mathrm{~d}$ & $62.5 \mathrm{~d}$ \\
\hline escription: $\mathrm{T}$ & $=$ Flo & $\begin{array}{l}\text { ss Ter } \\
\text { - shor }\end{array}$ & $\begin{array}{l}\text { TDK }= \\
\text { value } \mathrm{c}\end{array}$ & $\begin{array}{l}\text { eat Leaf Morin } \\
\text { en, shows the v }\end{array}$ & $\begin{array}{l}\text { L indicates the } \\
\text { te of } b+\end{array}$ \\
\hline
\end{tabular}

Statistical results on the physical properties (L, a-, b+, water absorption, starch gelatinization temperature) shows that there are significant differences in composite flour consisted of Tengger potato starch and moringa leaf powder ratio. The more the ratio of Moringa leaf powder, then decreasing levels of brightness (L) composite flour. Composite flour with potato starch ratio of Tengger and moringa leaf powder 100\%: $0 \%$ has a brightness level (L), the highest is 88.59 . The more the ratio of Moringa leaf powder then decrease the brightness.

Decreasing brightness index on the composite flour of Tengger potato starch and Moringa leaves powder caused by green color on colored moringa leaf powder dark green, but the brightness index composite flour including bright color indication for the value of the brightness (L) above 50 and still approaching the brightness levels of the flour that is 90 (Princess, 2014). According Hunterlab (2012), the range of dark color brightness values (L) is $0-50$, while the bright colors gentleness in the range of brightness values (L) that is 51-100.

The greenery value data (a-) showed that the more the ratio of Moringa leaf powder, then increasing the value of sulfur (a-). Composite flour with potato starch ratio of Tengger and moringa leaf powder 94\%: 6\% had a greenish value (a-), the highest is 1.56. Value is a chromatic color with greenish a- value (negative) from 0 to -80 (Hunterlab, 2012). The increase in green color is caused by chlorophyll pigments found in Moringa leaves. Pigment chlorophyll is green-brown pigment found in chloroplasts together with carotene and xantofil. Source of chlorophyll found in plants, fat and water soluble and sensitive to heat (Winarno, 2004).

The data yellowness value $(b+)$ showed that the more the ratio of Moringa leaf powder, it decreases the value of yellowness $(b+)$. Composite flour with potato starch ratio of Tengger and moringa leaf powder 100\%: $0 \%$ has a yellow value $(b+)$ high of 65.51 . According Hunterlab (2012) yellowness value is in the range of 0 to 70 with the notation $b *+$. Impairment yellowish composite flour potato starch ratio Tengger and moringa leaf powder, because the content of carotenoid pigments Tengger potato flour, potato flour as the ratio of the Tengger dwindling (Winarno, 2004). In addition, due to the increase in the ratio of Moringa leaf powder containing a greener pigment dark colored chlorophyll is used so that the yellow color of the Tengger potato starch will be reduced as it is covered by the green color of the leaves of Moringa powder.

On water absorption, the data showed that the more ratio of Moringa leaf powder, then increasing water absorption. Composite flour with potato starch ratio of Tengger and moringa leaf powder 96\%: $4 \%$ has the highest water absorption is $129.861 \%$. In empirically Xing-li et al (2016) the addition of potato flour in bread making can improve water absorption. Water absorption is affected by the protein in Moringa leaf powder. The percentage of water absorption can be influenced by the content of protein and crude fiber (Minerva, 2013). The content of protein in Moringa leaf powder can improve water absorption because it contains a structure in the form of functional groups $(\mathrm{NH} 2, \mathrm{NH}, \mathrm{OH}, \mathrm{CO})$ which can bind water molecules through hydrogen bonds (Trisnawati \& Nisa, 2015).

The water absorption ratio of composite flour composite flour ratio Tengger potato starch and flour of Moringa leaves are slightly smaller than the memepunyai flour, water absorption range of 160-170\% (Rauf and Sarbini, 2015). Water absorption in flour can affect the dough flower power, the higher the water absorption on foodstuffs, the higher the level of development of the bakery product dough during proofing (Hidayat et al, 2009).

The results of starch gelatinization temperature data shows that the more ratio of Moringa leaf powder, then increasing the temperature of the starch gelatinisai. Composite flour with potato starch ratio of Tengger and moringa leaf powder 94\%: 6\% had the highest starch gelatinization temperature $62,5 \mathrm{oC}$. Starch gelatinization temperature depends on the concentration of starch. The more viscous starch solution, then the temperature will be slower reached, until the temperature has not increased viscosity and starch could get damaged (Winarno, 2004). Based on this, carbohydrate levels can affect the gelatinization temperature of starch. The higher the carbohydrate content of the composite flour potato starch ratio Tengger and moringa leaf powder, then the lower the starch gelatinization temperature when grilling. Vice versa, the lower the carbohydrate content which will increase the gelatinization temperature of starch.

According to Winarno (2004) wheat flour gelatinization temperature ranges between $54,5-64 \mathrm{oC}$. Based on this composite flour gelatinization temperature of potato starch ratio Tengger and moringa leaf powder in accordance with the standard of wheat flour gelatinization temperature.

\section{CONCLUSION}

The ratio of composite flour and potato starch flour Moringa leaves Tengger significantly different with the 
Flour Processed Modification Method Using Partial Pragelatinisasi. Journal of Industrial Technology and Agricultural Products. 14: 2 best composite flour which is approaching the characteristics of wheat flour is composite flour with a ratio of potato starch Tengger and flour of Moringa leaves 94\%: 6\% moisture content $9.940 \mathrm{~g} / 100 \mathrm{~g}$, ash content of $2.045 \mathrm{~g} / 100 \mathrm{~g}$, protein content of $3.090 \mathrm{~g} /$ $100 \mathrm{~g}$, levels $0.286 \mathrm{~g}$ fat $/ 100 \mathrm{~g}$, crude fiber content of $0.597 \mathrm{~g} / 100 \mathrm{~g}$, carbohydrate levels $84.638 \mathrm{~g} / 100 \mathrm{~g}$, and the physical properties include brightness level of 82.79 , the value of 1.56 greenish, yellowish 59.66 value, water absorption $129.861 \%$, and the starch gelatinization temperature $62,5 \mathrm{oC}$

\section{REFERENCES}

[1] Abata, Qorry 'Aina. Food Allergy 2014: Resources, Risk Management \& Handling. Madiun. Yayaysan PP Al-Furqan

[2] Amalia, R., Julianti, E., and Ridwansyah. 2014 Physicochemical Characteristics of Composite Flour-Based Rice, Sweet Potato, Potato, Soybean, and Xanthan Gum. Journal of Food and Agricultural Engineering. 2 (2)

[3] AOAC. 2011. Official Methods Of Analysis of the Association of Official AnalyticalChemist. Associaton Of Official Analytical Chemists. Washington, DC

[4] AOAC. 2016. Official Methods Of Analysis of the Association of Official AnalyticalChemist. Associaton Of Official Analytical Chemists. Washington, DC

[5] Astuti, Ari, Tri. 2016. Relationship Between Food Consumption Pattern Containing Gluten and Casein with Autistic Behavior In Autism Special School in Yogyakarta. Respati Medical Journal. 11 (1)

[6] Augustyn, GH, Tuhumury, Goddess, HC, \& Dahoklory, Matheos. 2017. Effect of Adding Wheat Leaf Moringa (Moringa oleifera) Against Chemical Characteristics Appearance And Confectionery Mocaf (Modified Cassava Flour). Journal of Agricultural Technology. 6 (2): $52-58$

[7] National Standardization Agency. 2009. Information Bulletin Latest SNI. Jakarta (Online) Ginting, Faith., Julianti, Elisa, and Nainggolan, Rina J. 2015. Physicochemical Characteristics

[8] Flour-Based Composites Sweet Potato Flour, Starch Corn and Soybean Meal. Food and agricultural engineering. 3: 1

[9] Gopalakrishnan, Lakhsmipriya., Doriya, Kruthi., And Kumar, Devarai, S. 2016. Moringa oliefera: A Review on Medicial Nutritive Importance and Its Application. Food Science and Human Wellness. 5: 49-56

[10] Hand, Dwi Yuli. October 3, 2016. 600 Hectares Seed Potato Shortage Agrosari. Central FM Lumajang.

[11] Herminiati, Ainia. 2009. Dietary Foods for persons with Autism. Food articles. Issue 54.

[12] Hidayat, Beni., Kalsum, Nurbani., And Surfiana. 2009. Characterization of Cassava
[13] Hidayat, Rachman. Farming and 2017. Analysis of Factors Affecting Farmers Income Chips (Case Study Bumiaji Batu). Unpublished thesis. Poor. Malang State University.

[14] Hunterlab. 2012. Hunter L, a, b vs. CIE L *, a *, $\mathrm{b} *$ : Measuring Color Using the Hunter L, a, $\mathrm{b}$ versus the CIE $1976 \mathrm{~L} *, \mathrm{a} *, \mathrm{~b} *$. Hunter Associates Laboratory Inc.http: // www.Hunterlab.com

[15] Khoirunnisa, Lutfia and Judiono. 2018. Overview Gluten and Casein Intake in Children Patients with Autism in Children Growth Clinic Hospital Al-Islam Bandung. Journal of Health Research Department of Health Polytechnic Bandung. 10: 1

[16] Kiranawati, Titi, Pearl., Harijono., Estiasih, Teti, and Sriwahyuni, Endang. $2 \backslash 012$. Nutrient Content of Moringa (Moringa oleifera Lamk) Powder Leaves under Different Blanching Methods. Journal of Food and Public Health. 2 (6): 296-300

[17] Kiranawati, Titi, M., Nurjanah, Nunung., Wibowotomo, Budi., And Eun, Jong-Bang. 2019.

[18] Development of composite flour-based biscuits (ratio Potato Flour and Wheat Leaf Moringa) As GFCF Diet Food for People with Autism, Poor. Malang State University. The article has not been published.

[19] Krisnadi, A, D. 2015. Kelor Super Nutrition. Center for Information and Development Moringa Plant Indonesia. E-book moringa.com. Blora.

[20] Kusnandar. 2010. Food Chemistry Component Macro. Jakarta: Dian Rakyat

[21] Maulida, Faisal, Rithy. August 14, 2015. Given the Culinary Solutions Chips Typical Tengger tribe. Malang Times.

[22] Martawijaya, Eagle, L., Martanto, Eko, and Tinaprilla, Netti. 2004. Free Raising Ducks Laying In Intensive. Tangerang: PT. Agro Media Library

[23] Minerva, Elza, Mercitara. 2013. Effect of Mixed difference suweg And Wheat Flour Moringa Leaves Against Water Absorption Flour, Flower Power And Power Thank Crackers. Scientific manuscripts. Surakarta. Universitas Muhammadiyah Surakarta (online)

[24] Nurcahyati, Erna. 2014. Efficacy Powerful Moringa leaves. Jakarta: Window Healthy

[25] Paradibta, Inna. 2011. Physicochemical and Sensory Characteristics of Snack Bars Pondoh Tempe with the addition of Dry. Unpublished thesis. Surakarta. Sebelas Maret University.

[26] Daughter, Meddiati, Fajri, 2014. The content of the Nutrition and Physical Properties of Starch Dregs Coconuts As Food Ingredients Source of Fiber. Journal Teknobuga. 1 (1)

[27] Rauf, Rusdin and Sarbini, Dwi. 2015. Water Absorption For Reference To Determine Water 
Volume In Making Dough Bread From Wheat Flour Mix and cassava flour. Journal Agritech. $35(3)$

[28] Sarma, Irfan, S., Tamrin., And Ansar. 2018. Effect of Long Immersion Sago Flour (Metroxylon robbt) with Sari Bengkoang (Pachyrrhizuserosus) Characteristics Against Physical, Chemical and Organoleptic Sago Flour. Journal of Food Science and Technology. 3 (6): 1448-1459

[29] Trisnawati, Merina, Ling and Nisa, Fithri, Choirun. 2015. Effect of Adding Protein Concentrate Moringa leaves and Carrageenan on the Quality of Dried Noodle Substitution Mocaf. Journal of Food and Agro-industry. 3 (1): 237-247

[30] Widowati, S. 2009. Various Flour Tuber A Food Security Solution. Center for Agricultural Postharvest Research and Development. Published in Tabloid Sinar Tani, May 6th, 2009

[31] Winarno, FG 2004. Chemistry of Food and Nutrition. Jakarta: PT Gramedia Pustaka Utama Winarno, FG 2013. Autism and the Role of Food. Jakarta: PT Gramedia Pustaka Utama

[32] Winarno, FG 2018. The Moringa Plant: Nutritional Value, Benefits, and Potensiu Enterprises. Jakarta: PT Gramedia Pustaka Utama

[33] Xing-li, LIU., Tai-hua, MU., Hong-nan, SUN., Miao, ZHANG, Jing-wang, CHEN. 2016. Influence of Potato Flour on Dough rheological properties and Quality of Steamed Bread. Journal of Integrative Agriculture. 15 (11): 2666-2676

[34] Yulianto, Eko, Dawn. 2019. Effect of Addition Granola Potato (Solanum tuberosum) Junggo and Tengger Against Brownish index, and Flower Power (Basic Quality and passions) Pizza Dough. Unpublished thesis. Poor. Malang State University 